\title{
HUBUNGAN KONSUMSI KARBOHIDRAT SEDERHANA DAN CAIRAN TERHADAP KADAR ASAM URAT PADA REMAJA LAKI - LAKI
}

\author{
Dea Mustika Hapsari, Binar Panunggal") \\ Program Studi Ilmu Gizi Fakultas Kedokteran Universitas Diponegoro \\ J1.Dr.Sutomo No.18, Semarang, Telp (024) 8453708, Email : gizifk@ undip.ac.id
}

\begin{abstract}
Background: Increased of health risk in adolescent such as obesity and metabolic syndrom became a great concern. Serum uric acid levels may be a marker for risk various disease in adolescents. In addition high purine intake, consumption of simple carbohydrate also can increased uric acid levels. Meanwhile, high fluid consumption can reduced uric acid levels. The aim of this study was determined correlation of simple carbohydrates consumption and fluid to uric acid levels in boys adolescent.

Method: Observasional study used cross sectional design that involved 60 boys adolescent aged 16 to 18 years in SMAN 2 Slawi. Data obtained from simple carbohydrates intake interview directly using Food Frequency Questionnaire (FFQ) semi-quantitative and dietary data were assessed from 24-hour dietary recall interview for fluid consumption. Level of uric acid in the blood was measured by enzymatic PAP uricase method. The result was analyzed using rank Spearman and r Pearson Test.

Result: The mean of uric acid levels was $(5,842 \pm 0,97 \mathrm{mg} / \mathrm{dl})$. There were 6,7\% of subjects had high level of uric acid or hyperuricemia and 93,3\% had normal range of uric acid. 18,3\% subject simple carbohydrates consumption was high, more than 67 gram per day and 58,3\% subject with adequate fluid intake (>90\%). It was found that there was correlation between simple carbohydrates consumption with uric acid levels $(r=0.291, p=0.024)$. There was no correlation between fluid consumption with uric acid levels $(r=0.052, p=0.696)$.

Conclusion: There is significant correlation between simple carbohydrates consumption with uric acid levels, but no correlation between fluid consumption with uric acid levels in boys adolescent.
\end{abstract}

Keywords: simple carbohydrates; fluid; uric acid level; boys adolescent

\begin{abstract}
ABSTRAK
Latar Belakang: Meningkatnya risiko kesehatan seperti obesitas dan sindrom metabolik pada remaja, menjadi perhatian yang besar. Kadar asam urat dapat menjadi penanda risiko berbagai penyakit pada remaja. Selain asupan purin yang tinggi, konsumsi karbohidrat sederhana juga dapat mempengaruhi peningkatan kadar asam urat. Sementara, konsumsi cairan yang tinggi dapat menurunkan kadar asam urat. Tujuan penelitian ini untuk mengetahui hubungan konsumsi karbohidrat sederhana dan cairan terhadap kadar asam urat pada remaja lakilaki.

Metode: Penelitian obeservasional menggunakan desain cross sectional yang melibatkan 60 remaja laki - laki berusia 16 sampai 18 tahun di SMAN 2 Slawi. Data konsumsi karbohidrat sederhana diperoleh secara langsung menggunakan Food Frequency Questionnaire (FFQ) semi-quantitative dan data konsumsi cairan diperoleh menggunakan wawancara dengan dietary recall 3x24 jam. Kadar asam urat dalam darah diukur dengan metode enzimatik PAP uricase. Hasil yang diperoleh dianalisis menggunakan uji rank Spearman dan r Pearson Test.

Hasil: Sebanyak 6,7\% subjek memiliki kadar asam urat tinggi dan 93,3\% subjek memiliki kadar asam urat dalam batasan normal dengan rerata 5,842 $\pm 0,97 \mathrm{mg} / \mathrm{dl}$. 18,3\% subjek dengan konsumsi karbohidrat sederhana dalam kategori tinggi, yaitu lebih dari 67 gram per hari dan sebanyak 58,3\% subjek memiliki konsumsi cairan yang baik (>90\%). Hubungan yang bermakna antara konsumsi karbohidrat sederhana dengan kadar asam urat ( $r=0,291$, $p=0,024)$. Tidak terdapat hubungan yang bermakna antara konsumsi cairan dengan kadar asam urat $(r=0,052$, $p=0,696)$.
\end{abstract}

Simpulan: Terdapat hubungan yang bermakna antara konsumsi karbohidrat sederhana dengan kadar asam urat, konsumsi cairan tidak berhubungan dengan kadar asam urat pada remaja laki-laki.

Kata kunci: karbohidrat sederhana; cairan; kadar asam urat; remaja laki-laki

\section{PENDAHULUAN}

Periode remaja merupakan tahap transisi dari anak - anak menuju dewasa Pada periode ini terjadi banyak perubahan pada segi fisik dan perilaku, yang berawal dari usia 10 tahun dan berakhir di usia 18 tahun. Perubahan lain yang terjadi pada remaja adalah perilaku dalam pemilihan makanan yang dipengaruhi oleh keluarga, teman sebaya dan lingkungan. Remaja akan cenderung mengkonsumsi makanan cepat saji (fast food) yang tinggi energi dan lemak, makanan ringan tinggi natrium, dan minuman manis serta bersoda. Kebiasaan makan yang tidak baik semasa remaja akan berdampak pada fase kehidupan

\footnotetext{
${ }^{*}$ Penulis Penanggungjawab
} 
selanjutnya, setelah dewasa dan berusia lanjut. ${ }^{1}$ Meningkatnya risiko kesehatan pada remaja, seperti obesitas dan sindrom metabolik menjadi perhatian yang besar. Beberapa penelitian menunjukkan bahwa kadar asam urat berhubungan dengan komponen dari metabolik sindrom. ${ }^{2}$ Kadar serum asam urat dapat menjadi penanda risiko berbagai penyakit dan berpotensi terhadap perkembangan penyakit pada masa remaja yang dapat berlanjut hingga dewasa. ${ }^{3}$

Asam urat merupakan produk akhir metabolisme basa purin adenin dan guanin dari DNA dan RNA pada manusia. Nilai normal kadar asam urat bervariasi menurut usia dan jenis kelamin. Kadar asam urat normal pada laki - laki adalah 3,4 - 7,0 mg/dl dan 2,4 - 6,0 mg/dl pada perempuan. ${ }^{4}$ Pada remaja nilai kadar asam urat berada di batasan normal, namun pada laki - laki kadar ini akan mulai meningkat selama masa pubertas mulai berlangsung karena pada laki - laki tidak memiliki hormon estrogen yang bersifat uricosuric. Kadar asam urat dalam darah di atas normal, $\geq 7 \mathrm{mg} / \mathrm{dl}$ pada laki - laki dan $\geq 6 \mathrm{mg} / \mathrm{dl}$ pada perempuan disebut hiperurisemia. ${ }^{5}$ Penelitian menunjukkan bahwa serum kadar asam urat dihubungkan dengan sindrom metabolik pada anak - anak dan remaja. ${ }^{6}$ Selain asupan purin dan alkohol yang tinggi, konsumsi karbohidrat sederhana jenis fruktosa dan cairan mempengaruhi nilai kadar asam urat darah. ${ }^{4}$

Konsumsi karbohidrat sederhana atau gula pada remaja meningkat, terutama yang bersumber dari konsumsi soft drink menjadi sumber kalori utama. Karbohidrat sederhana terdiri dari monosakarida dan disakarida. Saat ini penambahan karbohidrat sederhana dalam bentuk gula fruktosa, termasuk sukrosa pada industri makanan semakin meningkat. Data yang didapat dari penelitian oleh National Center for Health Statistic CDC menyatakan $16 \%$ total kalori anak dan remaja berasal dari gula tambahan, dan 40\% kalori tersebut adalah karbohidrat sederhana dalam bentuk gula yang berasal dari minuman ringan. ${ }^{7} \mathrm{Di}$ Amerika soft drink dan minuman buah dalam kemasan menyumbang 10,6\% dari total kebutuhan energi, diikuti oleh kue dan biskuit $(3,6 \%)$ dan fast food $(3,1 \%) .{ }^{8}$ Sementara itu asupan karbohidrat sederhana melebihi batas yang dianjurkan WHO yaitu kurang dari $10 \%$ dari total kebutuhan sehari. ${ }^{9}$ Konsumsi karbohidrat sederhana terutama jenis sukrosa dan fruktosa dapat menstimulasi pembentukan asam urat melalui senyawa antara purin catabolic pathway. ${ }^{10}$ Dua penelitian epidemiologi sebelumnya pada dewasa menunjukkan bahwa konsumsi soft drink berhubungan dengan peningkatan kadar asam urat. ${ }^{8}$ Data dari Survei Kesehatan nasional di Amerika dari 4.867 remaja usia 12 - 18 tahun, menunjukkan bahwa konsumsi soft drink mengandung fruktosa 75 gram per hari, terjadi peningkatan kadar asam urat sebesar $0,50 \mathrm{mg} / \mathrm{dl} .{ }^{6}$

Konsumsi cairan yang adekuat selama remaja sangat penting dan akan mendukung fungsi tubuh, seperti menjaga tubuh remaja dari masalah dehidrasi dan mencegah dari beberapa masalah kesehatan yang akan muncul selama masa remaja. Kebutuhan cairan individu berbeda tergantung dari usia, jenis kelamin, dan aktivitas fisik. Kebutuhan cairan saat remaja akan meningkat, dan direkomendasikan sedikitnya 2,3 sampai 3 liter air per hari menurut Dietary Reference Intake (DRI). ${ }^{11}$ Air dan cairan lainnya berfungsi menjaga kelembapan kulit, mengatur suhu tubuh, dan membantu kerja ginjal dalam mengekskresikan zat sisa metabolisme. Asam urat merupakan hasil metabolisme tubuh yang diekskresikan ginjal dalam urin. Konsumsi cairan dalam jumlah yang tinggi akan membantu ginjal dalam mengekskresikan asam urat, sehingga kadar asam urat dalam tubuh dapat terjaga. Cairan yang dikonsumsi dapat berasal dari air minum, soft drink, dan makanan yang di konsumsi sehari hari. ${ }^{11,12}$

Konsumsi karbohidrat sederhana berhubungan dengan obesitas pada anak dan remaja, konsumsi cairan yang berhubungan dengan penurunan kadar asam urat. Penelitian mengenai konsumsi karbohidrat sederhana dan cairan terhadap kadar asam urat pada remaja di Indonesia masih terbatas. Berdasarkan uraian diatas, peneliti tertarik untuk mengetahui hubungan konsumsi karbohidrat sederhana dan cairan terhadap kadar asam urat pada remaja laki - laki.

\section{METODE PENELITIAN}

Penelitian ini dilaksanakan di SMA Negeri 2 Slawi pada bulan Agustus sampai September 2014. Penelitian ini merupakan penelitian observasional dengan pendekatan cross sectional. Populasi pada penelitian ini adalah seluruh siswa laki - laki kelas 2 dan 3 sejumlah 250 orang. Kriteria inklusi yang ditetapkan dalam penelitian antara lain adalah bersedia menjadi subjek penelitian, bersedia mengisi informed consent, memiliki status gizi normal dilihat dari Indeks Massa Tubuh persentil berdasarkan umur (IMT/U) $15-85^{\text {th }}$ persentil, memiliki lingkar pinggang $<90 \mathrm{~cm}$, tidak mengkonsumsi alkohol, tidak mengkonsumsi suplemen, obat - obatan atau jamu penurun kadar asam urat, tidak sedang dalam 
perawatan dokter atau menderita penyakit kronik. Kriteria eksklusi adalah subjek mengundurkan diri saat penelitian berlangsung.

Pengambilan subjek diawali dengan melakukan skrining terhadap siswa laki - laki yang berusia $16-18$ tahun dengan pengukuran antropometri untuk menentukan status gizi dan pengisian kuesioner mengenai kriteria inklusi. Data status gizi diperoleh dari pengukuran antropometri berupa tinggi badan, berat badan, dan lingkar pinggang. Subjek yang memiliki Indeks Massa Tubuh (IMT) persentil $15-85^{\text {th }}$ berdasarkan umur dan ukuran lingkar pinggang $<90 \mathrm{~cm}$ dikategorikan normal. Sebanyak 60 orang sesuai dengan kriteria inklusi diambil dengan cara simple random sampling.

Data yang dikumpulkan dalam penelitian ini meliputi karakteristik subjek penelitian, jumlah konsumsi karbohidrat sederhana dan cairan, dan kadar asam urat. Data karakteristik subjek meliputi identitas subjek. Konsumsi karbohidrat sederhana adalah karbohidrat sederhana dalam bentuk gula yang masuk ke dalam tubuh yang berasal dari makanan dan minuman baik yang sengaja ditambahkan maupun yang alami terdapat dalam bahan makanan dan minuman. Jumlah konsumsi karbohidrat sederhana diperoleh dengan menggunakan formulir FFQ (Food Frequency Questionaire) semi kuantitatif. Data asupan yang diperoleh (ukuran rumah tangga) dikonversikan ke dalam satuan gram kemudian dihitung nilainya menggunakan program Nutrisurvey dan dibandingkan dengan kebutuhan. Data konsumsi karbohidrat sederhana dikategorikan berdasarkan rekomendasi dari WHO, konsumsi karbohidrat sederhana tinggi apabila $>10 \%$ dari total kebutuhan energi, ${ }^{9,13}$ yaitu 67 gram per hari untuk laki - laki berdasarkan Angka Kecukupan Gizi (AKG) 2013.

Konsumsi cairan adalah jumlah asupan cairan yang masuk ke dalam tubuh dari semua makanan dan jenis minuman. Jumlah konsumsi cairan diperoleh dari dietary recall selama $3 \times 24$ jam pada 2 hari aktif dan 1 hari libur. Data konsumsi cairan (ukuran rumah tangga) dikonversikan ke dalam satuan $\mathrm{ml}$ (mililiter). Perhitungan jumlah total konsumsi cairan dihitung dengan menambahkan total cairan dari minuman dan makanan yang dilihat dari daftar DKBM 2009, kemudian dihitung rata - rata total konsumsi cairan selama $3 \times 24$ jam. Rata - rata total konsumsi sehari dibandingkan dengan kebutuhan cairan masing - masing individu menggunakan rumus Darrow, yaitu konsumsi air $=1.500 \mathrm{ml}+$ $20 \mathrm{ml}$ untuk setiap kilogram $(\mathrm{kg})$ kenaikan BB di atas $20 \mathrm{~kg}$. Pemenuhan kecukupan konsumsi cairan dikategorikan kurang apabila $<90 \%$ dan baik apabila > 90\%.,14 Data kadar asam urat didefinisikan sebagai jumlah asam urat dalam serum yang diukur dengan enzimatik kolorimetri. Metode dimana asam urat dioksidasi oleh uricase untuk diubah menjadi allantoin dan hidrogen peroksida. ${ }^{15}$ Sebelum pengambilan kadar asam urat, subjek melakukan puasa terlebih dahulu selama 10 sampai 12 jam.

Pengolahan dan analisis data dilakukan dengan menggunakan program komputer. Analisis data yang dilakukan adalah univariat untuk mendeskripsikan data identitas subjek, status gizi, data konsumsi gula sederhana, cairan, dan kadar asam urat. Data yang telah diperoleh diuji normalitasnya menggunakan uji KolmogorovSmirnov karena jumlah sampel $>50$. Analisis bivariat digunakan untuk mengetahui hubungan konsumsi gula sederhana dengan kadar asam urat menggunakan uji korelasi rank Spearman sedangkan hubungan konsumsi cairan dengan kadar asam urat menggunakan uji $r$ Pearson Test.

\section{HASIL PENELITIAN Karaksteristik Subjek}

Hasil skrining awal dengan melakukan pengukuran berat badan, tinggi badan, dan lingkar pinggang yang dilakukan pada 250 subjek siswa SMA laki - laki, diperoleh sebanyak 60 subjek dengan status gizi normal dilihat dari IMT persentil berdasarkan umur sesuai kriteria inklusi. Usia sampel dalam penelitian berkisar $16-18$ tahun, sebagian besar subjek berusia 17 tahun, sebanyak 24 orang siswa.

Tabel 1. Nilai Rerata dan Median pada Usia, Lingkar Pinggang, IMT persentil, Kadar Asam Urat, Konsumsi Karbohidrat Sederhana, dan Cairan

\begin{tabular}{llll}
\hline Variabel & Min & Max & $\begin{array}{c}\text { Mean } \pm \text { SD atau } \\
\text { Median }\end{array}$ \\
\hline Usia & 16 & 18 & $16,87 \pm 0,76(17,0)$ \\
Lingkar Pinggang (cm) & 63,7 & 76,7 & $71,02 \pm 3(70,9)$ \\
IMT Persentil & 30,0 & 78,5 & $50,61 \pm 11,7(50,6)$ \\
Kadar Asam Urat (mg/dl) & 3,6 & 7,8 & $5,84 \pm 0,97(6,0)$ \\
Konsumsi Karbohidrat Sederhana (gr) & 20,0 & 114,2 & $54,55 \pm 18,5(52,75)$ \\
Konsumsi Cairan (ml) & 1690 & 3000 & $2367,7 \pm 365,5(2320)$ \\
\hline
\end{tabular}


Pada Tabel 1, dalam penelitian menunjukkan rerata lingkar pinggang subjek adalah $71,0 \pm 3 \mathrm{~cm}$ yang berkisar antara 63,7 sampai $76,7 \mathrm{~cm}$. IMT persentil berdasarkan umur subjek berkisar antara 30,0 sampai 78,5 persentil dengan rerata 50,6 $\pm 11,7$ persentil. Distribusi frekuensi subjek berdasarkan kategori variabel penelitian dapat dilihat pada Tabel 2.

Tabel 2. Distribusi Frekuensi Kategori Konsumsi Karbohidrat Sederhana, Cairan dan Kadar Asam Urat Subjek

\begin{tabular}{lcc}
\hline \multicolumn{1}{c}{ Variabel } & n & Persen (\%) \\
\hline Konsumsi Karbohidrat Sederhana & & \\
$-\quad$ Normal $(<67$ gr) & 49 & 81,7 \\
$-\quad$ Tinggi $(>67$ gr) & 11 & 18,3 \\
Konsumsi Cairan & & \\
$-\quad$ Baik $(>90 \%)$ & 35 & 58,3 \\
$-\quad$ Kurang $(<90 \%)$ & 25 & 41,7 \\
Kadar Asam Urat & \multicolumn{2}{|}{} \\
$-\quad$ Normal $(3,4-7 \mathrm{mg} / \mathrm{dl})$ & 56 & 93,3 \\
$-\quad$ Tinggi $(>7 \mathrm{mg} / \mathrm{dl})$ & 4 & 6,7 \\
\hline
\end{tabular}

Kadar asam urat subjek berkisar antara 3,6 sampai $7,8 \mathrm{mg} / \mathrm{dl}$ dengan nilai median $6,0 \mathrm{mg} / \mathrm{dl}$. Tabel 2 menunjukkan bahwa 60 subjek yang diperoleh sebanyak 93,9 \% $\quad(n=56)$ subjek memiliki kadar asam urat dalam batas normal antara 3,4-7 mg/dl dan 6,7\% (n=4) memiliki kadar asam urat tinggi diatas $7 \mathrm{mg} / \mathrm{dl}$. Jumlah konsumsi gula sederhana subjek berkisar antara 20,0 sampai 114,2 gram per hari dengan nilai median 52,75 gram. Tabel 2 menunjukkan sebagian besar subjek yang mengkonsumsi gula sederhana dalam kategori normal $<67$ gram per hari sebesar $81,7 \% \quad(\mathrm{n}=49)$ dan sisanya $18,3 \%$ $(\mathrm{n}=11)$ mengkonsumsi gula sederhana dalam kategori tinggi $>67$ gram per hari. Jenis makanan dan minuman yang paling banyak dikonsumsi oleh subjek saat penelitian dilakukan antara lain, minuman ringan manis dalam kemasan (soft drink), cokelat, es krim, dan semua makanan yang manis.

Konsumsi cairan subjek berkisar antara 1690 sampai $3000 \mathrm{ml}$ dengan rata - rata $2367,7 \pm 365,5 \mathrm{ml}$. Tabel 2 menunjukkan sebesar $58,3 \%(\mathrm{n}=35)$ konsumsi cairan dalam kategori baik $(>90 \%)$ dan sebesar $41,7 \% \quad(n=25)$ masih dalam kategori kurang $(<90 \%)$ dibandingkan dari kebutuhan. Cairan yang dikonsumsi oleh para remaja sebagian besar dari minuman antara lain air mineral, kemudian teh manis dan semua jenis minuman yang manis baik dalam kemasan maupun tidak.

Tabel 3. Tabulasi Silang Kategori Konsumsi Karbohidrat Sederhana dengan Kadar Asam Urat

\begin{tabular}{lccc}
\hline \multirow{2}{*}{ Variabel } & \multicolumn{2}{c}{ Kadar Asam Urat (mg/dl) } & \multirow{2}{*}{ Total } \\
\cline { 2 - 3 } & Normal & Tinggi & \\
\hline Konsumsi Karbohidrat Sederhana (gr) & 49 & & \\
$-\quad$ Normal & 7 & - & 49 \\
$-\quad$ Tinggi & 56 & 4 & 11 \\
Total & 33 & & 60 \\
\hline Konsumsi Cairan (ml) & 33 & 3 & \\
$-\quad$ Baik & 56 & 1 & 36 \\
$-\quad$ Kurang & 4 & 24 \\
Total & & & 60 \\
\hline
\end{tabular}

Berdasarkan hasil penelitian, hampir sebagian besar subjek menunjukkan bahwa konsumsi karbohidrat sederhana dalam kategori normal dengan kadar asam urat normal adalah sebanyak 49 subjek. Sebanyak 4 orang subjek dengan konsumsi karbohidrat sederhana tinggi dan kadar asam urat subjek dalam kategori tinggi. Sebagian besar subjek $(\mathrm{n}=33)$ dengan kadar asam urat normal, konsumsi cairan mereka dalam kategori baik. 3 orang subjek dengan konsumsi cairan baik dengan kadar asam urat dalam kategori tinggi. Distribusi frekuensi kategori variabel berdasarkan tabel tabulasi silang penelitian dapat dilihat pada tabel 3 .

\section{Hubungan Konsumsi Karbohidrat Sederhana dan Cairan dengan Kadar Asam Urat}

Tabel 4 menunjukkan korealsi antara variabel - variabel yang diteliti berdasarkan uji korelasi menggunakan uji rank Spearman menunjukkan bahwa konsumsi gula sederhana 
memiliki hubungan yang bermakna dengan kadar asam urat $(\mathrm{p}=0,024)$ dan menunjukkan arah korelasi positif $(r=0,291)$. Sementara itu jumlah konsumsi cairan yang diuji menggunakan uji $r$
Pearson menunjukkan cairan tidak memiliki hubungan dengan kadar asam urat dengan nilai ( $\mathrm{p}$ $=0,696)$.

Tabel 4. Hubungan Konsumsi Karbohidrat Sederhana dan Cairan dengan Kadar Asam Urat

\begin{tabular}{lcc}
\hline \multicolumn{1}{c}{ Variabel } & \multicolumn{2}{c}{ Kadar Asam Urat (mg/dl) } \\
\cline { 2 - 3 } & $\mathbf{r}$ & $\mathbf{p}$ \\
\hline Konsumsi Karbohidrat Sederhana (gr) & 0,291 & $0,024^{\mathrm{a}}$ \\
Konsumsi Cairan (ml) & 0,051 & $0,696^{\mathrm{b}}$ \\
\hline
\end{tabular}

${ }^{\mathrm{a}} \mathrm{Uji}$ Korelasi $R$ Spearman, ${ }^{\mathrm{b}} \mathrm{Uji}$ Korelasi $r$ Pearson

\section{PEMBAHASAN}

Hasil penelitian yang dilakukan pada 60 orang subjek remaja laki - laki usia 16 - 18 tahun terkait dengan kadar asam urat menunjukkan sebanyak 4 orang subjek $(6,7 \%)$ memiliki kadar asam urat yang tinggi atau hiperurisemia dan sebagian besar subjek $(93,3 \%)$ memiliki kadar asam urat dalam rentang yang normal, dengan rata - rata kadar asam urat subjek adalah 5,84 mg/dl. Kadar asam urat merupakan bahan normal di dalam tubuh yang merupakan produk akhir metabolisme purin. Keseimbangan antara produksi dan ekskresi asam urat menentukan kadar asam urat dalam darah. ${ }^{4}$ Peningkatan produksi asam urat akan diikuti oleh peningkatan ekskresi asam urat dalam kondisi yang normal. Kejadian hiperurisemia sering terjadi pada laki - laki hal ini berkaitan dengan tidak adanya hormon esterogen seperti pada wanita yang bersifat uricosuric yang dapat meningkatkan ekskresi dari asam urat. ${ }^{16}$ Penelitian yang dilakukan di Taiwan pada 70.108 subjek dengan usia dibawah 18 tahun dengan IMT normal menunjukkan bahwa rata - rata kadar asam urat sebesar $5,2 \mathrm{mg} / \mathrm{dl} .^{3}$

Sebuah penelitian menyatakan bahwa risiko masalah kesehatan akan muncul saat kadar asam urat lebih dari $5,5 \mathrm{mg} / \mathrm{dl}$. Sebuah studi yang dilakukan pada subjek remaja usia $6-18$ tahun menemukan bahwa remaja dengan kadar asam urat $>5,5 \mathrm{mg} / \mathrm{dl}$ mengalami hipertensi primer. $^{17}$ Penelitian lain yang dilakukan pada subjek yang berbeda yaitu pada dewasa menunjukkan bahwa serum kadar asam urat berisiko mengakibatkan penyakit kardiovaskuler, bahkan dalam kisaran kadar yang normal. Kadar asam urat juga telah dikaitkan dengan risiko terjadinya penyakit kardiovaskuler dan sindrom metabolik pada remaja yang dapat berkembang hingga dewasa. ${ }^{18}$

Hasil penelitian diperoleh sebanyak 11 subjek (18,3\%) memiliki asupan karbohidrat sederhana tinggi, sedangkan sebagian besar subjek asupan karbohidrat sederhana dalam batas normal $<67$ gram per hari. Penelitian ini menemukan bahwa terdapat hubungan antara konsumsi karbohidrat sederhana dengan kadar asam urat $(\mathrm{p}=$ $0,024)$ dan menunjukkan arah korelasi positif $(\mathrm{r}=$ 0,291), artinya semakin tinggi konsumsi karbohidrat sederhana maka semakin tinggi kadar asam urat. Karbohidrat sederhana atau gula mengacu pada monosakarida dan disakarida. Monosakarida terdiri dari glukosa, galaktosa, dan fruktosa. Disakarida meliputi sukrosa, laktosa, dan maltosa. Umumnya jenis disakarida adalah sukrosa yang tersusun dari dua molekul gula sederhana yaitu glukosa dan fruktosa, banyak ditemukan di gula tebu (sugar cane) dan gula bit (sugar beets) yang sering ditambahkan atau dimasukkan ke dalam makanan, minuman buah, dan minuman lainnya. ${ }^{19}$ Hasil penelitian ini sejalan dengan teori yang ada, menyebutkan dimana karbohidrat gula sederhana jenis fruktosa dapat meningkatkan kadar asam urat apabila dikonsumsi dalam jumlah yang berlebih. Metabolisme utama fruktosa terdapat di hati. Mekanisme karbohidrat sederhana atau gula jenis sukrosa yang berisi fruktosa atau dalam bentuk fruktosa bebas dalam menginduksi terbentuknya asam urat adalah dengan melalui fosforilasi fruktosa menjadi fruktosa 1-fosfat yang diubah oleh enzim ketoheksokinase (KHC) yang dengan cepat akan menghabiskan penggunaan ATP. Penggunaan ATP yang berlebih menyebabkan pembentukan asam urat melalui senyawa antara adenosin monofosfat (AMP) dan inosin monofosfat (IMP). ${ }^{8,10}$

Hasil wawancara dari Food Frequency Questionnaire (FFQ) dalam penelitian menemukan bahwa subjek dengan asupan karbohidrat sederhana atau gula yang tinggi terutama empat orang subjek yang memiliki kadar asam urat tinggi atau hiperurisemia gemar mengkonsumsi minuman ringan manis kemasan (soft drink), cokelat, es krim, kue, permen, hingga jus buah dalam kemasan. Menurut penelitian yang dilakukan NHANES (National Health and Nutrition Examination Survey) yang dilakukan di Amerika Serikat pada remaja mengemukakan bahwa mereka 
yang gemar mengkonsumsi soft drink $>425 \mathrm{ml} /$ hari atau > 1 kaleng per hari meningkatkan kadar asam urat sebesar $0,18 \mathrm{mg} / \mathrm{dl} .^{6}$

Pada penelitian ini konsumsi cairan terhadap kadar asam urat secara statistik tidak menunjukkan hubungan bermakna $(\mathrm{p}=0,696)$. Penelitian yang sama tentang asupan cairan terhadap kadar asam urat namun pada subjek yang berbeda yaitu pada 40 wanita usia 50 - 60 tahun juga menunjukkan hasil yang sama bahwa tidak ada hubungan yang bermakna $(p>0,05)$ antara asupan cairan dengan kadar asam urat. Pada penelitian tersebut menjelaskan bahwa rata - rata konsumsi cairan wanita usia 50 - 60 tahun tersebut berada dalam kategori cukup dan sebagian besar sudah mengkonsumsi cairan dalam jumlah lebih dari $1500 \mathrm{ml}$ per hari.

Hasil dari penelitian yang diperoleh tentang konsumsi cairan pada subjek, rata - rata berkisar $2367 \mathrm{ml}$ per hari. Konsumsi cairan dari 35 orang subjek berada dalam kategori baik (>90\%) dibandingkan dengan kebutuhan, sedangkan 25 orang subjek konsumsi cairan dalam kategori kurang $(<90 \%)$ dari total kebutuhan. The American Dietetic Association Nutrition menyatakan bahwa konsumsi cairan dalam jumlah adekuat ( 8 gelas per hari) diperlukan untuk membantu ekskresi asam urat dan meminimalkan kemungkinan pembentukan batu ginjal karena penumpukan asam urat di urin. ${ }^{20}$ Meningkatkan konsumsi cairan bertujuan untuk mempertahankan output urin lebih banyak serta menjaga kelarutan urin agar tidak pekat, sehingga pembuangan zat sisa metabolisme salah satunya asam urat akan meningkat. Jenis cairan yang dikonsumsi juga mempengaruhi ekskresi dari asam urat dalam urin. Air mineral merupakan salah satu jenis cairan yang paling baik, dapat membantu mencegah terjadinya penumpukan asam urat pada urin. ${ }^{21}$

Hasil dietary recall 24 jam yang didapatkan dari wawancara langsung pada subjek, menunjukkan bahwa jenis cairan yang paling sering dikonsumsi subjek adalah air mineral, teh manis dan soft drink. Secara uji statistik variabel konsumsi cairan tidak memiliki hubungan dengan kadar asam urat. Hal ini mungkin dapat dipengaruhi oleh cairan yang dikonsumsi oleh subjek tidak langsung mempengaruhi ekskresi kadar asam urat dalam urin mereka. Dalam hal ini peningkatan ekskresi asam urat dalam tubuh dipengaruhi oleh faktor selain konsumsi cairan, yaitu konsentrasi volume plasma, kecepatan aliran ginjal, $\mathrm{pH}$ urin dan obat - obatan. ${ }^{22}$ Ekskresi normal dari asam urat hanya $8 \%$ sampai $12 \%$. Selain dari faktor konsumsi cairan, reabsorpsi dan sekresi merupakan faktor utama yang mengatur jumlah ekskresi asam urat. ${ }^{23}$ Sehingga kadar asam urat pada subjek berbeda - beda namun masih dalam batas normal. Sebagian besar subjek mengkonsumsi air mineral dalam kategori baik. Konsumsi cairan dalam jumlah yang tinggi akan menyebabkan tekanan protein plasma darah menurun, sehingga sekresi hormon ADH yang akan mempengaruhi produksi urin terhalang, sehingga reabsorpsi air oleh tubulus akan menjadi kurang efektif. Hal ini mengakibatkan kondisi urin menjadi encer dan yang terbentuk menjadi banyak, ekskresi zat terlarut dalam air seperti asam urat akan meningkat. ${ }^{24}$

Selain dipengaruhi oleh diet makanan dan minuman sehari - hari, kadar asam urat juga dipengaruhi oleh mekanisme pembentukan asam urat di dalam tubuh dan kemampuan ekskresi asam urat oleh tubuh. Konsumsi karbohidrat sederhana pada sebagian besar subjek berada dalam kategori normal, begitu juga dengan konsumsi cairan yang berada dalam kategori baik yang menyebabkan kadar asam urat pada subjek sebagian besar berada dalam kisaran normal.

\section{SIMPULAN}

Kadar asam urat subjek rata - rata dalam batas normal 93,3\% $(n=56)$ subjek dan 6,7\% $(n=4)$ dengan kadar asam urat tinggi atau hiperurisemia. Konsumsi karbohidrat sederhana subjek sebagian besar dalam kategori normal 81,7\% ( $\mathrm{n}=49)$ subjek dan sebanyak 58,3\% (n=35) subjek konsumsi cairan dalam kategori baik. Terdapat hubungan antara konsumsi karbohidrat sederhana dengan kadar asam urat, tetapi tidak terdapat hubungan antara konsumsi cairan dengan kadar asam urat pada remaja laki - laki.

\section{SARAN}

Kadar serum asam urat dapat menjadi penanda risiko berbagai penyakit dan berpotensi terhadap perkembangan penyakit pada masa remaja yang dapat berlanjut hingga dewasa. Kadar asam urat yang berada diatas batas normal akan menimbulkan risiko terjadinya penyakit. Untuk mencegah terjadinya penyakit yang berhubungan dengan asam urat pada remaja, perlu dilakukan pembatasan pada makanan dan minuman yang mengandung terlalu banyak karbohidrat sederhana dalam hal ini bentuk gula sederhana $<10 \%$ dai total kebutuhan sehari/ Selain itu konsumsi cairan yang cukup pada masa remaja menghindarkan remaja dari beberapa masalah kesehatan salah satunya yang berhubungan dengan asam urat. Batasi konsumsi cairan yang mengandung tinggi 
karbohidrat atau gula sederhana terutama jenis sukrosa dan fruktosa.

Saran bagi penelitian selanjutnya adalah agar meneliti konsumsi cairan dengan membedakan jenis - jenis cairan yang dikonsumsi dari minuman serta dari makanan

\section{DAFTAR PUSTAKA}

1. Arisman. Gizi dalam daur kehidupan. Jakarta: Penerbit Buku Kedokteran EGC; 2002. P 6271.

2. Tang L, Kubota M, Nagai K, Mamemoto K, Tokuda M. Hyperuricemia in obese children and adolescents: the relationship of metabolic syndrome. Pediatric reports 2010; 2(2): 38 41.

3. Wang, JY, Chen YL, Hsu, CH, Tang, SH, Wu CZ, Pei D. Predictive value of serum uric acid levels for diagnosis of metabolic syndrome in adolescents. The Journal of Pediatrics 2012;161: pp $753-6$.

4. Nelms M, Sucher KP, Lacey K, Roth SR. Nutrition therapy and patophysiology. 2nd edition. United State: Cengange; 2010. P 2301 $-5$.

5. Isselbacher. Harrison prinsip - prinsip ilmu penyakit dalam. Asdie HA, editor Vol 5. Ed 13. Jakarta: Penerbit Buku Kedokteran EGC; 2000. P $2301-05$.

6. Nguyen S, Choi HK, Lustig RH, Hsu CY. Sweetened beverages, serum uric acid, and blood pressure in adolescents. J Pediatric, 2009 June; 154 (6): 807 - 813.

7. Brian KK, Margaret DC, Cynthia LO. Consumption of added sugar among U.S. children and adolescents, 2005 - 2008. National Center for Health Statistic, CDC. NHCS Data Brief, March 2012; 87: 1-7.

8. Gao X, Qi L, Qiao N, et al. Intake of added sugar and sugar-sweetened drink and serum uric acid concentration in US men and women. Hypertension 2007; 50: 306-12.

9. World Health Organization. WHO draft line sugar guideline. Geneva. 2014. [Cited 2014 May 6]. Avalaible from: URL: HYPERLINK http://www.who.int/mediacentre/news/notes/2 014/consultation-sugar-guideline/en/.

10. Van den B. Fructose metabolism and shortterm effects on carbohydrate and purine metabolism pathways. Prog Biochem Pharmaco; 1986; 21 : pp 1 - 32.

11. World Health Organization. Water requirements, impinging factors, and recommended intakes. Geneva. 2004.
12. Erdman J. Dietary reference intake for water, pottasium, sodium, chloride, and sulfate. Institute of Medicine. Washington. 2005. p. $93-185$.

13. Ira X, Shankar B, Srinivasan CS. Dietary recommendations in the report of a joint WHO/FAO expert consultation on diet, nutrition and the prevention of chronic disease (WHO Technical Report Series 916, 2003): Potential impact on consumption, production, and trade of selected food products, 2003.

14. Departemen Kesehatan. Rencana pembangunan kesehatan menuju indonesia sehat 2010. 2006. [Cited 2014 June 12]. Avalaible from: URL: HYPERLINK www.depkes.go.id.

15. Febrianti C, Wathoni N, Hasanah AN. Validasi metode analisis kadar asam urat dalam reseptor kromatografi cair kinerja tinggi. Jurnal unpad 2012;1(1):1-3.

16. Saag KG, Choi HK, Epidemiology, risk factor, and lifestyle modification for gout. Arthritis Research \& Therapy 2006, 8 Suppl $1: 1-7$.

17. Daniel IF, Richard JJ. Hypeuricemia in childhood primary hypertension. Hypertension, Sept 2003; 42 (3): pp. 247 252.

18. Daniel IF, Kang DH, Richard JJ. Uric acid and cardivascular risk. N Engl J Med, 2008 Oct 23; 357(17): $1811-21$.

19. Howard BV, Rosset JW. Sugar and cardiovascular disease. Circulation, 2002; 106: 523 - 27.

20. Hayman S, Marcason W. Gout: is a purinerestricted diet still recommended? J Am Diet Assoc 109:1652, 2009.

21. National Institute Health. Diet for kidney stone prevention. National Kidney and Urologic Disease Information, February 2013; 13: $1-3$.

22. Mount DB, Kwon CY, Zandi-Nejad K. Renal urate transport. Rheum Dis Clin North Am 2006, 32:313-331, vi.

23. Gary SF, Ralph CB, Sherine EG, Lain Bmc, and James RO. Kelley's textbook of rheumatology, 9th edition. 2013. pp $1535-$ 45.

24. Ramel FR, Guisan B. Renal transport of urate in humans. J Am Physiol. Sci 1999;14:80-84. 